\title{
Managerial incentives and strategic choices of firms with different ownership structures
}

\author{
Shantanu Banerjee ${ }^{a *}$ and Swarnodeep Homroy ${ }^{b}$
}

October 3, 2017

\begin{abstract}
We examine how ownership structure affects managerial incentive alignment mechanisms and strategic objectives. We compare large Indian firms with dispersed equity ownership with business-group affiliates operating within the same institutional frameworks. We find that the performance sensitivity of CEO pay and turnover differ significantly across group affiliates and stand-alone firms. The strategic choices of firms also differ in response to managerial incentives. However, we find that, regardless of those differences, firm performance is similar for both types of firms. Overall, this paper suggests that ownership structure and managerial incentives can adjust to optimize strategic choices and firm performance.

Keywords: Corporate Governance, Controlling Shareholders, Firm Performance, Strategic Choices, India

\section{JEL Classification: G30, G32, G34}

${ }^{*}$ Corresponding Author: Department of Accounting and Finance, ${ }^{a}$ Lancaster University Management School, Lancaster, LA1 4YX, United Kingdom. ${ }^{b}$ Department of Economics, Econometrics, and Finance, University of Groningen, 9700 AV, Netherlands.

E-mail address: s.banerjee@lancaster.ac.uk

Acknowledgement: The authors thank Sudipto Dasgupta, Paolo Fulghieri, Amiyatosh Purnanandam, Raghavendra Rau, and participants of the IFABS 2015 Oxford conference and the Work, Pensions, and Employment Group, Sheffield, 2015 annual conference, for their suggestions. We also thank the anonymous referee and the Editor for constructive comments.
\end{abstract}




\section{Introduction}

Business groups with concentrated ownership structures, often via a founding family are a common organizational form in emerging economies. Although debate over the relative costs and benefits of group affiliation is long standing, variations in managerial incentives and business strategy have received little empirical attention. In this paper we examine managerial incentive alignment mechanisms in firms with different ownership structures, and we examine how such incentives are associated with firm strategy and performance.

A popular view is that concentrated shareholding of the founding family is associated with weaker corporate governance (La Porta et al., 1999; Gibson, 2003). Holderness (2009) notes that most U.S. firms have large blockholders who may have conflicts of interest with managers and small shareholders. Moreover, dual class shares in the U.S. and the pyramid structure of cross-holdings in East Asian countries can lead to wide variations between control and cash flow rights (Masulis, et al., 2009, Classens et al., 2002), as well as expropriation of minority shareholders. Bertrand et al. (2002) find evidence of expropriation through tunneling of resources. Expropriation can lower the performance of group affiliates versus that of widely held firms (Holderness and Sheehan, 1988; Cronqvist and Nilsson, 2003). If institutional and minority

investors rationally expect these costs, it will reflect in the stock prices of the group affiliates (Masulis et al., 2011).

There are many reasons for forming a business group. First, concentrated shareholding and family control offer the benefits of intergenerational ownership stakes and strong reputational concerns. This "Stewardship" role can improve firm performance (Anderson and Reeb, 2003; Maury, 2006). Business group affiliates can also leverage investments, production, and information through common ownership, while generating financing advantages through intra-firm loans (Gopalan et al., 2007). Khanna and Yafeh (2007) find that business groups are more common in markets with less developed institutions and are often formed with government support. Family-controlled business groups can reduce transaction costs with outsiders in an environment of inadequate laws but they can continue to exist when legal protection is adequate.

We examine the differences among incentive structures, strategic priorities and competitive- 
ness between business group affiliates and stand-alone firms. Firms with different ownership structures naturally face different agency and transaction costs. Thus, we expect managerial incentive alignment mechanisms to differ as well. To that end, we use data from large listed Indian firms to compare incentives across business group affiliates and stand-alone firms. Specifically, we focus on differences in the performance sensitivities of CEO pay and CEO turnover between group affiliates and stand-alone firms with dispersed shareholding.

Our results suggest that CEO pay is higher in business group affiliates, but pay-performance sensitivity is also higher. On the other hand, CEO turnover is more sensitive to performance in widely-held firms than to that in business group affiliates. We distinguish further within a business group between firms with CEOs from the controlling family, and firms with outside CEOs. We find that firms with outside CEOs in group affiliates tend to offer managerial incentive structures that are similar to that of the CEOs in unaffiliated firms. Collectively, our results suggest that firms with different ownership structures tend to feature different kinds of incentive alignment mechanisms: performance-sensitive CEO pay (carrot-type incentives) and performance-sensitive CEO turnovers (stick-type incentives) 11 In business group affiliates with a family-CEO and intergenerational stakeholding, we find that carrot-type incentives are commonly used, while CEOs of widely held stand-alone firms are more likely to be at risk for dismissal over poor performance. However, we also find that, when business group affiliates have outside CEOs, the incentive alignment structure is similar to that in stand-alone dispersed shareholding firms. These types of incentives are not mutually exclusive but under incomplete managerial contracting, one of the two types tend to dominate.

Next, we investigate how managerial incentive design is associated with the strategic choices of business group firms and widely-held firms. There is some evidence that managerial incentives affect firm strategy (Ederer and Manso, 2016; Manso, 2011; Croci and Petmezas, 2015; Low, 2009). Siegel and Choudhury (2012) argue that affiliate firms of business groups pursue different strategies than unaffiliated firms, which we must consider when examining expropriation mechanisms in business groups. We compare group affiliates and unaffiliated firms on long-

\footnotetext{
${ }^{1}$ Our definition of a stick-type incentive is based on the likelihood of CEO dismissal for poor performance. This is different from Dittman, Maug and Spalt (2010) formulation of minimum wage CEO pay as a stick type incentive within a loss-aversion framework.
} 
and short-term strategic objectives. Stand-alone widely held firms tend to emphasize short-term strategic goals such as the current ratio and the asset-turnover ratio; business group affiliates tend to focus more on long-term investments in research and development (R\&D) and capital expenditures. We interpret these results to mean that faced with stick-type incentives, managers of stand-alone firms will prioritize shorter-term targets. The controlling shareholders of business group affiliates, because they enjoy longer-term control over their firms, generally invest more in longer-term strategies.

Finally, we examine the implications of the differences in incentive alignment and strategic objectives for firm performance. We find that performance does not seem to vary systematically with ownership structure. Notwithstanding the differences in managerial incentives and strategic priorities, firm performance appears similar for Indian business group affiliates and for widely held stand-alone firms.

We use data from Indian firms for several distinct considerations. First, India provides a unique setting from which to compare firms with different ownership structures within the same institutional and legal framework. Anglo-American type dispersed ownership firms, and concentrated shareholding insider-dominated business groups such as East-Asian firms are both common in India. Among the top 500 Indian firms, which constitute $99 \%$ of market capitalization, $32.67 \%$ are affiliates of diversified business groups, $17.63 \%$ are controlled by the state, and 49.7\% are Anglo-American-style stand-alone firms with dispersed shareholding. Second, India has a mature capital market, so the financial information and industry classifications are largely consistent and comparable (Jameson et al., 2014). Recent regulations in India have aimed to make governance frameworks and reporting standards consistent with those in the U.S. and the EU.

The economic liberalization of the Indian economy in 1991 relaxed investment and trade barriers and increased competition in most industries. The proportion of widely-held firms increased during the post-liberalization period. In this environment, the concurrent increase in competition would drive out less efficient ownership structures, but both business group affiliates and dispersed ownership firms have continued to coexist successfully for over two decades. In contrast, in Japan and South Korea, keiretsus and chaebols, respectively, have long been the 
dominant organizational forms, and the institutional framework has evolved to support them. The presence of both business group affiliates with concentrated shareholding and widely held stand-alone firms within the same regulatory and accounting framework allows us to overcome many of the shortcomings of cross-country comparisons of corporate governance (Kaplan, 1994, 1997).

Our paper contributes to several strands of the corporate finance literature. First, we contribute to the literature on managerial incentives by comparing incentive design in business group affiliates and stand-alone firms. While there is some evidence of the incentives in business group firms, we provide direct comparative evidence on managerial incentives in group affiliates and stand-alone firms. For example, Gibson (2003) shows, for firms with concentrated ownership, that CEO turnover is not sensitive to performance and Croci et al. (2012) report lower CEO pay in European family firms than in unaffiliated firms. In contrast, our results provide evidence of the relative dominance of pay-performance (carrot-type) and turnover-performance (stick-type) incentives across group affiliates and stand-alone firms. Moreover, we show that the incentives of outside CEOs in group affiliates resemble those of CEOs in stand-alone firms. These results contribute to the literature by providing clear evidence of differences in managerial incentives in firms with different ownership structures.

Second, our results contribute to the literature on how managerial incentives may be correlated with firm strategy. Empirical evidence on the strategic choices of firms with different ownership structures is scant. Croci and Petmezas (2015), Low (2009), and Armstrong and Vasistha (2012) show that CEO compensation design affects risk-taking incentives and firm value. In contrast, we show that the planning horizons of managers vary with incentive structure. For example, managers in group affiliates with carrot-type incentives make long-term investments, while managers in stand-alone firms with stick-type incentives emphasize shorter-term strategic measures. This is consistent with Ederer and Manso's (2016) experimental evidence, which shows that the threat of CEO turnover decreases, while entrenchment increases the incentives for longer-term strategies such as innovation.

In this paper, we follow the approach of Siegel and Choudhury (2012) who argue that differences in strategic choice need to be considered when examining whether business groups serve 
as a mechanism for financial redistribution, or expropriation. While they examine how business group affiliates react to industry shocks, we examine the interrelationships among ownership structure, managerial incentives, and strategic priorities.

Finally, there has been little consensus thus far on how ownership structure is related to firm performance. Jameson et al. (2014) study the impact of having family members on boards. They find that the involvement of controlling shareholders in governance adversely affects firm performance. On the other hand, Demsetz and Lehn (1985) suggest that the structure of corporate ownership varies in ways that are consistent with value maximization. Our focus here is primarily on the effect of group affiliation and ownership structure on firm performance. Our results suggest there are no systematic performance differences between group affiliates and stand-alone firms. This confirms the view that agency costs arising out of the separation of ownership and control act to counterbalance the transaction costs of enforcing incomplete contracts.

The remainder of this paper proceeds as follows. Section 2 provides some background on Indian corporate governance structures and our empirical motivation. Section 3 describes our data, while section 4 discusses the econometric methods and our results. Section 5 concludes.

\section{Empirical Motivation}

\subsection{Institutional background}

The institutional framework for corporate governance in India dates back to 1875 with the establishment of the Bombay Stock Exchange (BSE). The Companies Act of 1956, which governed the activities of listed firms in India, was subsequently replaced by the Companies Act of 2013. Since the liberalization of the economy in 1991, the role of government has reduced, with a shift away from the traditional interventionism and toward a more Anglo-American style of governance. Indian firms have thus become increasingly reliant on external sources of finance.

La Porta et al. (1999) classify India as having a high shareholder rights index, on par with the U.K., the U.S., Canada, Hong Kong, and other English-origin common law countries. Given the power of the Securities and Exchange Board of India (SEBI), the primary regulatory authority, India scores highly on measures of investor protection, the procedural clarity of its judiciary, 
and its level of disclosure requirement. However, these are undermined by long delays in the completion of court cases. India falls in the bottom $25 \%$ on indices for the enforcement of rule of law and corruption.

In an attempt to improve the corporate governance scenario, SEBI enacted Clause 49 of the Listing Agreement for all firms listed in the BSE 200 index from 2001 onward. Similar to the 2002 Sarbanes-Oxley Act in the U.S., Clause 49 mandates clear governance standards for listed firms. These range from board composition and independence of the audit committee, to enhanced disclosure norms, and stronger requirements for corporate directors and officers to be responsible for financial statements and the monitoring of internal control systems. Such reforms brought India closer into line with developed capital markets, and have likely contributed to the increase in investments by foreign institutions.

In contrast to the mixed response to Sarbanes-Oxley in the U.S., Clause 49 had a significantly positive impact on stock returns (Khanna, and Yafeh, 2007; Chakrabarti et al., 2007). Note that Indian accounting standards are, largely aligned with International Financial Reporting Standards (IFRS), which makes verifying the reliability of information much easier. By 2005, all Indian listed firms had adopted the regulations of Clause 49, thereby enhancing transparency and comparability of the data.

Dispersed shareholding patterns in India are less common than in the U.S. or U.K. More than $17 \%$ of firms listed on the BSE are wholly or significantly controlled by the federal or state government, and three of the top six Indian firms in 2014 were public sector firms. The proportion of large stand-alone firms in India with a dispersed shareholding pattern only began to increase over the past twenty years. Currently, about half of the top 500 firms listed on the BSE feature western-style diversified shareholding where a professional manager has relatively little stake in the firm.

Diversified business groups, with family-centric controlling stakes are a major organizational form in the Indian corporate sector. A common characteristic is the presence and influence of "promoters"; i.e. controlling stakeholders who can be an individual or a family $2^{2}$ Promoters, on

\footnotetext{
${ }^{2}$ SEBI defines a promoter as "the person or persons who are in control of the company, directly or indirectly, whether as share holder, director or otherwise; or person or persons named as promoters in any document of offer of securities to the public or existing shareholders or in the shareholding pattern, disclosed by the company under the provisions of the Listing Agreement".
} 
average hold about $42 \%$ of shares in business-group firms ${ }^{3}$.

Although Indian business groups share some characteristics of an interconnected business relationship structures with a Japanese keiretsu, several key differences set them apart. On the one hand both structures feature individual firms that are legally separate entities, that are primarily responsible to their own shareholders, and are audited separately. On the other hand, unlike a keiretsu, in which the affiliate firms are connected and coordinated through a common group-specific bank, the affiliate firms within an Indian business group are coordinated by interlocked boards and by members of the promoter family. In that respect their ownership structure resemble those of Korean chaebols (Khanna and Palepu, 2000). A typical Indian business group has dozens of firms with complex cross-holdings, which makes it difficult to compute the conventional measures of cash flow rights and voting rights.

The prevalence of business group firms in emerging markets such as India, raises questions about the sources of competitiveness of group affiliation. First, business groups may dominate industries of strategic importance. Such industries in India, like railways, national defense, and coal, for example, are nationalized and thus an unlikely source of competitive advantage. However, in emerging markets with weaker institutions, group affiliates may benefit from withingroup internal capital markets (Khanna and Palepu, 2000). They can also support financially weaker affiliates by means of intra-group loans and cash-transfers. An important reason for doing this is to avoid the negative spillover from default by an affiliate to the rest of the group (Gopalan et al., 2007)

Further, the strategic objectives of business group affiliates and stand-alone firms can be different. For example, during times of positive industry-wide demand shocks, group affiliates tend to increase operational expenses, while stand-alone firms tend to increase sales volume (Siegel and Choudhury, 2012). There may also be distinct differences in board composition, institutional shareholding, and the design of managerial incentives. In this paper, we explore those differences in incentive design, firm strategy and performance.

\footnotetext{
${ }^{3}$ Firms with dispersed shareholding structures may also have CEOs and board-members who are members of the founding family. However, their control over the firm is limited compared to business group affiliate firms with more concentrated shareholding and cross-holding structures.
} 


\subsection{Managerial incentive alignment mechanisms}

The evidence on how ownership structure impacts managerial incentives is limited mainly to cross-country comparisons. For example, Kaplan (1997) finds that U.S. market-based governance is no more effective at replacing poor performing CEOs than the relationship-oriented governance styles of Germany and Japan. Gibson (2003) finds that CEO turnover is not sensitive to performance in emerging economy firms with a concentrated shareholding. Empirical evidence suggests that institutional and legal frameworks are significantly correlated with ownership, performance, and governance (Demsetz and Lehn, 1985; La Porta et al., 1997). Therefore, the evidence based on a pooled sample of multiple countries cannot adequately control for the role of institutional and legal frameworks. Such variations in regulatory frameworks, data collection and methodology are among the major challenges to cross-country comparisons of corporate governance practices and outcomes (Bryson et al., 2014).

Single-country studies on how ownership structure affects managerial incentives have typi-

cally focussed on the differences between large and small firms (Black, et al., 2006) or between foreign and domestic holdings (Patibandla, 2006). Results indicate that larger firms, and firms with higher foreign institutional holdings are better governed. Some studies explore the governance in concentrated holding firms such as those within keiretsus or chaebols. These papers examine the effects of firm performance and CEO turnover (Berglof and Perotti, 1994; Kang and Shivdasani, 1995) and find that non-routine CEO turnover is negatively correlated with firm performance.

More recently, some evidence on the governance structure of Chinese firms observed that certain facets of western corporate governance are present in Chinese and East Asian firms (Conyon and He, 2011; Bryson et al., 2014). For example, managerial power played a prominent role in pay setting.

However, there is no direct evidence concerning the design of managerial incentive structure in group affiliates versus stand-alone firms. A priori, managerial incentives for a family-CEO with an intergenerational stake in a firm are likely to differ significantly from those of a professionally recruited risk-averse CEO with myopic loss aversion (Dittman et al., 2010). 


\subsection{Incentive design and strategic objectives}

Low (2009) finds that compensation design impacts manager's risk taking behavior. The effect can be multi-dimensional. Manso (2011), and Ederer and Manso (2016) argue that the threat of termination (stick-type incentives) can undermine managerial incentives for long-term strategies, such as innovation. They find that such strategies are better facilitated by longer-term rewards and managerial entrenchment.

As Siegel and Choudhury (2012) suggest, the correlation between managerial incentives and corporate strategy is important because firm strategies play an important role in the empirical investigation of governance and performance. They find differences between how Indian business group firms and stand-alone firms react to positive industry shocks. If managerial incentives between both groups differ, and incentive structures are tied to the planning horizon of strategy, we can expect strategic priorities of both types of firms to differ as well.

\subsection{Business group affiliation and firm performance}

Empirical evidence on corporate governance in emerging economies is focused mainly on the performance of group affiliates, relative to unaffiliated firms. Demsetz and Lehn (1985) show that ownership structure and firm performance vary in ways that are optimal for firm value, i.e. firm performance does not depend on ownership structure. However, tunneling of assets by the controlling stakeholders at the expense of minority shareholders in business groups remains a concern (Johnson et al., 2000; Bertrand et al., 2002). This problem can lead to inefficiency and competitive disadvantages. Bertrand et al. (2002) find that business group affiliates are $30 \%$ more likely to suffer earnings losses during industry shocks than western-style stand-alone firms in the same industry. However, firms at the lower tier of the pyramid are affected less by shocks because they are buffered somewhat by the assets of the firms at the top of the pyramid. Bertrand et al. (2002) suggest that the controlling stakeholders therefore benefit at the expense of minority shareholders. Also, Jameson et al. (2014) show that the performance of business group affiliates declines with board memberships of controlling shareholders. Neither higher institutional ownership nor greater board independence is found to mitigate this negative association. 
On the other hand, Khanna and Palepu (2000) find that affiliates of diversified Indian business groups can create internal processes to deal with institutional voids, and therefore perform better than stand-alone firms. Using data from forty-five countries, Masulis et al. (2011) show that group affiliation reduces financing constraints, which leads to greater investment intensity. Siegel and Choudhury (2012) show that group affiliates adjust their cost structure differently with respect to stand-alone firms when faced with a macro-level shock. Controlling for differences in business strategies, they find no evidence of tunnelling in Indian business groups.

A question thus arises: How do the different strategic priorities of business group affiliates affect firm performance? There does not appear to be any consensus thus far, particularly taking into account possible differences in incentive alignment mechanisms and strategic objectives between group affiliates and stand-alone firms.

\section{Data}

\subsection{Sample selection}

India has a mature capital market, so financial information and industry classifications are largely consistent and comparable. Our data come from the Prowess database, maintained by the Centre for Monitoring the Indian Economy, and we purposefully chose 2006-2013 for our sample because by 2005, Clause 49 had been implemented uniformly across all listed Indian

firms. As Siegel and Choudhury (2012) note, the survivorship bias in the early Prowess data had also been corrected by 2005, and in 2013, a new Companies Act had largely superseded the Act of 1956, most notably with respect to incorporation and director responsibilities.

For each year, we take the top 500 listed firms on the Bombay Stock Exchange which represent over $95 \%$ of total market capitalization. We follow each firms from the time it first enters BSE 500 within our sample period until the end of the sample period, even if it does not remain on the BSE 500. We exclude firms that go private, are acquired, or are delisted due to any other reasons. We also exclude public sector firms with significant government ownership and political appointments because they usually lend themselves poorly to comparisons. We find that public sector firms in India are disproportionately in strategically important industries such as defense, 
railways, and some forms of energy. The managerial incentives also differ significantly in public sector firms $4^{4}$ Similarly, we exclude foreign-owned firms, as well as firm-year observations with missing data on ownership, and firm performance measures. We obtain information on the education and experience of individual directors and CEOs from BoardEx, and merge it with Prowess 5

Our final sample consists of an unbalanced panel of 577 firms with 4,143 firm-year observations. The measurement and classification of firms' shareholding structures lie at the heart of our empirical strategy. We classify firms into two categories, Business Group Affiliates and Stand-Alone Firms, based on the two parameters of information from Prowess. First, we identify affiliate firms of business groups. Like many Asian countries, group firms in India are connected through equity ownership. In most cases, the controlling shareholder is a family, such as the Tata, Birla, Bajaj, or Ambani family, for example. Classifying firms as an affiliate of a business group is an inexact science. A firm is not entirely defined by either a certain percentage of equity ownership with a particular individual or family nor by the appointment of a family member as the CEO or Chairman. We use data available from Prowess and public filings to determine a company's association with a business group. We then create a binary indicator, Business Group Affiliates, which equals 1 for business group firms and 0 otherwise. While the binary classification is a relatively crude measure, it is consistent with those used in the literature on emerging market finance (Khanna and Palepu, 2000; Bertrand et al., 2002; Siegel and Choudhury, 2012).

Second, we identify shareholders who control a firm either directly through their own shareholding or indirectly through cross-holdings. In all our regressions we control for \% ShareholdingPromoters by combining direct shareholding of promoters with the proportion of shares held by persons acting in concert with promoters. This provides a measure of direct and indirect control of a firm by the promoters within business group firms.

Of the 577 firms in our sample, we classify 226 (39.16\%) as affiliate firms of business groups, and $351(60.83 \%)$ as stand-alone firms with dispersed shareholding. The affiliate firms of business groups are often connected through common family ownership and cross-holding between

\footnotetext{
${ }^{4}$ For example, CEOs or Managing Directors of public sector firms are fixed term bureaucratic appointments and the pay is contingent on tenure and rank.

${ }^{5}$ We use fuzzy-matching algorithms on firm names to merge BoardEx and Prowess, which gives us an $83 \%$ match or near-match. We also conduct a second-level of manual matching to complete the exercise.
} 
different group firms. They are also more likely to have a member of the promoter family as the CEO. Note that we make an important distinction here: Not all business group affiliated firms appoint CEOs from the controlling family. About $44 \%$ have outside CEOs. In our empirical analyses, we will investigate differences in incentive-alignment between business group affiliates with outside CEOs and those with family CEOs.

To further explore incentive alignment mechanisms, we define the top executive of a firm as the CEO, where "managing director" and "chief executive officer" are used interchangeably in the official job title. Prowess identifies the top executive of each firm provides but provides no information on whether the CEO is a founding family member. We therefore hand-collect that information from various firm filings (annual reports, statutory filings with the stock exchange, etc.).

CEO Pay in India is structured as fixed salary plus performance-based pay. This structure is similar across firms with both types of share-holding patterns. The performance-based component or variable pay, unlike the equity-based pay prevalent in western economies is generally paid out as cash bonuses and perquisites ${ }^{6}$. In our sample, variable averages about $28 \%$ of total CEO pay.

We combine the information from Prowess with our hand-collected data to generate the year of CEO resignation or retirement. We find 493 events of CEO turnover: 174 among the business group affiliates and 319 among stand-alone firms. Alternatively, we can measure of incentive alignment by the association between forced CEO turnover and firm performance. Because we do not know the circumstances of a CEO's departure, the classification of a forced or otherwise often relies on age- or press-based algorithms (Homroy, 2014; Peters and Wagner, 2014). Following Parrino (1997), we use a modified version of the most common algorithm in order to classify forced turnover as developed by Parrino (1997). In the absence of reliable and consistent press reports on CEO departures, we use CEO age at the time of departure to generate measures of forced turnover. This is because press-based algorithms would dramatically reduce the sample to include mostly the bigger and more visible firms, particularly for an emerging market sample. Furthermore, the actual reasons for CEO departures are often cloaked in euphemisms, hence

\footnotetext{
${ }^{6}$ Equity ownership and option grants for CEOs are present in some firms but they form a very small proportion of the total pay. We don't use these in our calculation of CEO pay.
} 
such content-analysis exercise could be inaccurate.

CEO age data come from BoardEx and the median age of CEO turnover in our sample is 61.45 years. We construct an indicator for forced turnover that equals 1 if the departing CEO is less than 60 years old 7 This gives us a sample of 244 events of forced CEO turnover: 163 in business group firms and 81 in stand-alone firms.

Next, we use a range of controls for board and director characteristics. information on board size, and number of independent directors come from Prowess. Following Clause-49 of SEBI, the mean proportion of independent directors on the board is expected to be at least 0.5 for all firms. In addition to the number of independent directors, we also control for the quality of directors. Using information on individual directors' education and experience from BoardEx, we identify a directors as Technical Directors if they hold a technical qualification and/or have served on specific board committees 8 in other firms. We classify postgraduate degrees in Engineering, Management, and doctoral degrees in STEM fields as technical qualifications. We check the sensitivity of our classification by only restricting only to degrees awarded by the highest ranked Indian and foreign universities and institutes. We encode the technical expertise of directors if they have served on one or more of the following committees: nomination, remuneration, or audit. We aggregate information on education and experience at the board level, and use a measure of Technical Directors as a proportion of independent non-executive directors. In certain specifications, we also control for the number of directors on the board from the controlling stakeholder family, excluding the CEO.

We also use accounting information from stand-alone annual financial statements reported by Prowess. We cross-check for the consistency by comparing it with information from Datastream by using a string-matching algorithm on the basis of firm names 9 In our baseline specifications, firm performance is measured by returns on assets $(R O A)$, and we control for firm size by using the natural log of sales 10 Key variable descriptions are in appendix A1.

\footnotetext{
${ }^{7}$ We test for robustness of our classification by using fifty-five and fifty years as our age threshholds.

${ }^{8}$ Data on director expertise and education is available from the authors upon request.

${ }^{9}$ In cases where the data from the two sources do not match exactly, we use the financial data from Prowess.

${ }^{10}$ We also check the robustness of our estimates with alternate measures of firm performance (Tobin's Q approximated by MTBV) and firm size (total assets).
} 


\subsection{Summary statistics}

Table 1 gives the summary statistics for corporate governance outcomes, firm characteristics, and board characteristics for the sample firms. All monetary variables are scaled by Consumer Price Indices published by the Government of India, and are in millions of US dollars. Sample firms are large, with mean sales of $\$ 522$ million. Average shareholding of the controlling shareholder (family) is about $41 \% 11$ We control for institutional shareholding by using the percentage of equity shares held by financial institutions such as mutual funds, banks, insurance companies, and venture capital funds (about $17 \%$ in the sample firms). Note that $37 \%$ of sample firms have a CEO from the promoter family ${ }^{12}$ The average board is comprised of 10 directors, $51 \%$ of whom are independent non-executive directors. Average CEO pay is $\$ 4.3$ million, and the average CEO turnover rate is $14.5 \%$.

[Table 1 around here]

The descriptive statistics in table 1 subsume heterogeneities across business group affiliates and unaffiliated firms with dispersed shareholding. The first concern is that business group affiliates and stand-alone firms operate in different industries with varying levels of competition. Therefore, if business group firms are over-represented in industries of strategic importance (such as coal, electricity generation and transportation, railways, or defense) this could explain how they persist in emerging markets. However, as we noted earlier, in India, these industries are almost exclusively served by public-sector firms.

Table 2 shows the industry distribution of business group affiliates and unaffiliated firms with dispersed shareholding. Both types of firms appear to exist throughout all industry groups, and therefore such industry classification does not seem to be the primary source of competitiveness. All of our baseline specifications include the Herfindahl-Hirschman Index (HHI) as a measure

\footnotetext{
${ }^{11} \mathrm{~A}$ problem may arise if the controlling stakeholders reduce their holdings over time. In that case, over our sample period we would expect to see more unaffiliated firms with dispersed holding at the expense of business group affiliates. However, we find no evidence of that, and we observe that holdings of promoter family generally remains stable over time. See the online appendix for the time-series variations of mean and median promoter shareholdings in business-group affiliates.

${ }^{12}$ Stand-alones can have family CEOs who are either founders or are from the family of large investors/shareholders. About $8 \%$ have family CEOs, but they typically have very low personal holdings in the firm.
} 
of industry competition, as well as industry dummies to control for other industry-level heterogeneities 13 In the next sub-section we present univariate comparisons of these two types of firms on all observable characteristics.

[Table 2 near here]

\subsection{Univariate analysis}

The central focus of our empirical analysis is on how the shareholding structure of firms is correlated with managerial incentives, firm strategy and firm performance. We conduct a univariate analysis in which we compare firm- and board-level characteristics of business group affiliates and stand-alone firms. The results in panels $\mathrm{A}$ and $\mathrm{B}$ of table 3 show the means and medians, respectively. The significance of the mean (median) is based on a two-tailed $t$-test (Wilcoxon test).

[Table 3 around here]

Business group affiliates on average are larger than stand-alone firms in terms of sales revenue and total assets. Consistent with our definition, promoters have larger shareholdings in business group affiliates, where CEOs have higher pay. However, no statistically significant difference in performance emerges between the two categories of firm ownership, nor between board-level characteristics or industry competition. Firms with different ownership structures differ on measures of short-term strategic focus (Asset Turnover Ratio and Current Ratio), and on longterm investments (R\&D Expenditures and Capital Expenditures). Business group affiliates and stand-alone firms differ in size and in measures of strategic initiatives, but there seems to be no significant difference in firm performance measures.

Table 4 shows that business group affiliates with family-CEOs have higher stakeholding by promoters, and higher CEO pay, as well as a lower rate of CEO turnovers and fewer directors from the promoter family. This may suggest that within business groups, two kinds of firms exist: 1) firms with a family CEO, higher family stakeholding, and fewer family members on the

\footnotetext{
${ }^{13}$ In the online appendix, we present the distribution of business group affiliates and unaffiliated firms with dispersed shareholding by quarties of industry competitiveness, as measured by the HHI. Both types of firms seem to be present in all quartiles of competitveness.
} 
board; 2) those with an outside CEO where controlling stakeholders have relatively more board seats.

In the following sections, we use multivariate analyses to investigate differences among incentive-alignment mechanisms, firm strategy and firm performance under different ownership structures.

[Table 4 around here]

\section{Empirical Strategy and Results}

This section describes our methods and the results of our empirical analysis. First, we examine the central question of the paper: How do managerial incentive alignment mechanisms vary with ownership structures? We also examine whether these mechanisms affects strategic choices. Finally, we assess how the financial performance of firms varies with ownership structure.

\subsection{Ownership structure and managerial incentives}

The univariate results suggest that significant differences in firm and managerial incentives exist between business group affiliates and stand-alone firms. To investigate managerial incentive alignment mechanisms, we specifically examine the performance sensitivities of CEO pay and CEO turnover, controlling for firm and board characteristics. This approach, consistent with Bryson et al. (2014) and Gibson (2003), is used to examine the incentive alignment and effectiveness of governance mechanisms. The performance sensitivities of CEO pay and CEO turnover in themselves are not sufficient to infer the degree to which incentive-alignment is effective. However, they form the necessary conditions for effective corporate governance and can thus be used as a reliable basis of comparison.

We first explore the managerial incentive alignment mechanisms for business group affiliates and unaffiliated firms with dispersed shareholding. To do this, we examine differences in incentive alignment for business group affiliates with and without family CEOs. One way to compare the incentives of business group affiliates with and without a family CEO is to identify events where a family $\mathrm{CEO}$ is replaced by an outside CEO, or vice-versa. Changes in CEO 
pay around such events can shed light on the differences in incentive-alignment mechanisms. In our sample such events are rare, and anecdotal evidence suggests that each of these events has some distinctive features. For example, Ratan Tata, the patriarch of the Tata Group, retired in 2012. Ratan Tata had never married and had no children. His successor was a non-Tata family member, Cyrus Mistry, a member of the Palonji family of Shapoorji Palonji and Company, who hold $9.5 \%$ of Tata Group stocks. A pay comparison around this change would not be very representative considering the relatively large stakeholding of the new outside CEO.Given the small number of such events and their special circumstances, we focus on a pooled cross-section of firms of both types in our empirical analyses.

To examine the performance sensitivity of CEO pay, we estimate the baseline specification:

$$
\begin{array}{r}
\text { CEOPay }=f\left(\alpha_{1} \text { ROA }+\alpha_{2}\right. \text { Business Group } \\
\text { Affiliates } \left.+\alpha_{3} \text { FamilyCEO }+\gamma Z_{i t}\right)
\end{array}
$$

where firm performance is measured by return on assets (ROA), $\alpha_{1}$ captures the effect of firm performance on CEO pay and $Z_{i t}$ is a vector of all control variables. This is a pooled crosssection regression without firm-fixed effects, because we are interested in the cross-sectional variations across the two types of ownership structures.

The key variable is Business Group Affiliates. Where $\alpha_{2}$ is positive and statistically significant, it indicates that CEOs of business group affiliates are paid more than CEOs of stand-alone firms. Similarly if $\alpha_{3}$ is positive, pay would be higher for CEOs who are members of a controlling family. To better examine the incentive alignment mechanism, we divide the business group firms into two subgroups: those with a family-CEO and those with an outside CEO. We run a version of specification (1) for these two subgroups and for stand-alone firms separately. The results are in table 5 .

Column (1) reports the estimates from Equation (1). We present the results for the subsamples of business group affiliates and stand-alone firms in columns (2)-(5). All estimates are reported with robust standard errors, clustered at firm level. Note that the coefficient on ROA 
is positive implying that CEO pay is generally sensitive to firm performance across both types of ownership structure. From column (1), the Business Group Affiliates indicator is positive and statistically significant, suggesting that CEOs of business group affiliates are paid more than their counterparts in stand-alone firms. Similarly, family CEOs are paid more than outside CEOs. However, the coefficients in columns (2)-(5) are not directly comparable, and do not provide an objective comparison of performance sensitivity of CEO pay across the two types of firms.

To provide a fuller comparison, in column (6) we add the interactions of $R O A * B u s i n e s s$ Groups with Family CEOs and ROA*Business Groups with Outside CEOs. We also use the interactions of all covariates with Business Groups with Family CEOs and Business Groups with Outside CEOs dummies. We also use the interactions of all covariates with Business Groups with Family CEOs and Business Groups with Outside CEOs with all covariates as regressors. This provides a nested model that allows objective comparison of the parameter estimates of $R O A *$ Business Groups with Family CEOs and ROA*Business Groups with Outside CEOs with respect to the reference group of CEOs in stand-alone firms.

[Table 5 around here]

The parameter estimate of $R O A *$ Business Groups with Family CEOs is positive and statistically significant at the $5 \%$ level while that of $R O A *$ Business Groups with Outside CEOs is positive but not statistically significant at conventional levels. To quantify, one standard deviation increase in ROA leads to a 0.24 standard deviation increase in CEO pay in business group affiliates with family CEOs, a 0.15 standard deviation increase in business group with outside CEOs, and a 0.11 standard deviation increase in CEO pay of stand-alone firms.

The results suggest that business group affiliates with family CEOs have a higher payperformance sensitivity (a carrot-type incentive), but no significant difference in CEO payperformance sensitivity exists for group affiliates with an outside CEO and stand-alone firms. We observe this higher pay-performance sensitivity after controlling for the incentive alignment generated by the shareholding of the promoters. This is consistent with the hypothesis that, when stick-type incentives are not credible, carrot-type incentives dominate 14

\footnotetext{
${ }^{14}$ The results are robust to alternate measures of firm performance. Note tjat the sensitivity is stronger for
} 
Next, we examine the performance sensitivity of CEO turnovers by estimating the following specification with a binary indicator of CEO turnover as the dependent variable:

$$
\begin{array}{r}
\text { Probability (ForcedTurnover })=f\left(\beta_{1} \text { FirmPerformance }+\beta_{2}\right. \text { Bu siness } \\
\text { GroupAffiliates } \left.+\beta_{3} \text { FamilyCEO }+\theta Z_{i t}\right)
\end{array}
$$

We measure firm performance by $R O A, Z_{i t}$ is a vector of other control variables and $f($.$) is a$ logit function. We follow a similar method of enquiry as equation (1) to examine whether poorerperforming CEOs of business group affiliates, and family CEOs are equally likely to be replaced with respect to outside CEOs in group affiliates. We also test this specification on a subsample of business group affiliates with family CEOs, business group firms with outside CEOs, and stand-alone firms. The results are presented in Table 6. Column (1) reports the estimates from Equation (2). We present the results for the subsamples of business group affiliates and standalone firms in columns (2)-(5). All estimates are reported with robust standard errors clustered at the firm level.

The coefficient of $R O A$ is negative and statistically significant, suggesting that CEOs are typically replaced for poor performance. But the coefficient on the Business Group indicator is negative. Therefor, CEOs of business group affiliates and family CEOs are less likely to be replaced for poor performance. Similarly to Table 5, we estimate the performance sensitivity of forced CEO turnover in column (6) by adding the interactions of $R O A *$ Business Groups with Family CEOs and ROA* Business Groups with Outside CEOs. In addition, we use the interactions of all covariates with Business Groups with Family CEOs and Business Groups with Outside CEOs. dummies. This allows us to compare the performance sensitivity of CEO turnover for group affiliates with and without a family $\mathrm{CEO}$, with respect to the base group of stand-alone firms within a nested specification.

[Table 6 around here]

accounting performance relative to that for MTBV. This is perhaps driven by the fact that the pay for Indian CEOs is structured so that the performance-based bonus is contingent on the accounting performance of the firm. 
The parameter estimate of $R O A *$ Business Groups with Family CEOs is negative but not statistically significant at conventional levels. For family CEOs in business group affiliates, there is no significant association between the likelihood of turnover and firm performance. The performance sensitivity of CEO turnovers in business group firms with an outside CEO seems similar to that of stand-alone firms. This is consistent with the notion of stick-type incentives dominating carrot-type incentives. The coefficient of $R O A$ in column 3 is not statistically different from zero: We conclude that, for promoter CEOs in business group firms, stick-type incentives are not effective. The presented results are the marginal effects from the logit regressions. Following Powers (2005) and Buis (2010), we calculate the marginal effects at the mean, taking into account the potential bias in interaction terms in logit regressions 15 To quantify, the likelihood of forced turnover for an average CEO of a business group affiliate is 2 percentage points lower than that for an average CEO in a widely held firm. The likelihood of forced turnover for family CEOs in poorly performing business group firms is also lower than that for an outside CEO in a poorly performing business group firm. The nested logit results are conistent with the estimates from the nested linear probability model in column (7).

Together, these results provide new evidence on incentive alignment mechanisms in firms with differing shareholding structures. Given the costs associated with administering a complete contract, the incentive alignment mechanisms vary so that in a way that either the stick-type or the carrot-type dominates in firms with different ownership structures.

\subsection{Ownership structure, firm strategy, and firm performance}

In this section, we examine the effect of ownership structure, and managerial incentives on the strategic choices of firms. As we showed above, carrot-type incentives dominate for CEOs in business group firms, and stick-type incentives dominate for CEOs in widely held firms. We examine whether these incentives are associated with the strategic choices of the CEO. For example, a professional CEO with a stick-type incentive may be more inclined to emphasize short-term objectives. On the other hand, a family CEO, for whom carrot-type incentives

\footnotetext{
${ }^{15}$ Recent versions of certain statistical packages such as Stata 15 can calculate marginal effects separately for each category in a binary or factor variable. For a detailed discussion on the marginal effects of interaction terms in non-linear models, see Buis (2010) and Williams (2012).
} 
dominate, is likely to prioritize long-term strategies. We examine whether there is any differences in priorities based on two long-term strategic measures (capital expenditure and research and development expenditure) and two short-term measures (asset-turnover and current ratios). We choose these measures as a proxy for the time-horizon of the strategic focus. Note that high current ratio might mean that a firm's short-term financial position is relatively secure, but it may also suggest that the firm is not using its liquid assets effectively. Either way, we can argue that that higher current ratio has short-term benefits. Similarly, other things equal, higher asset turnover ratio indicates more efficient use of the assets in place but a CEO with short term incentives may be tempted to improve this ratio by cutting down capital expenditure on profitable long term investment opportunities. On the other hand, the returns to long-term investments like research and development expenses accrue over a longer time horizon. Hence we interpret it as a measure of long-term strategic focus.

Table 7 presents our results. The dependent variables in columns (1) and (2) are short-term strategy measures: the asset-turnover-ratio and the current ratio respectively. The dependent variables in columns (3) and (4) are the long-term measures: R\&D and Capital Expenditures. The main regressor is the Business Group Affiliates indicator, which captures the difference in strategy between business group affiliates and stand-alone entities. In columns (1) and (2), this indicator is negative and significant for measures reflecting short-term strategies. However, it is positive and significant for the long-term measures (columns (3) and (4)). Moreover, business group affiliates with family CEOs are likely to prefer longer-term investment over short-term strategies, as is seen from the coefficient of the interaction term,Family CEO*BusinessGroup Affiliates. It is positive and significant for long-term strategic measures, but not statistically significant for short-term measures. These results are consistent with Siegel and Choudhury's (2012) argument that group affiliates and stand-alone firms have different strategic priorities, and thus have different incentive alignment mechanisms.

[Table 7 around here]

However, in spite of the differences in strategic choices and incentive alignment mechanisms, a firm's objective is difficult to examine except through the lens of shareholder value maximization. 
Therefore, we consider whether these differences lead to differences in performance of business group affiliates with respect to stand-alone firms. We estimate the specification:

$$
\text { FirmPerformace }=f\left(\delta B u \sin e s s \text { Group Affiliates }+\lambda X_{i t}\right)
$$

where Business Group Affiliates is an indicator of shareholding structure, and $X_{i t}$ is a vector of all firm and board-level observable variables. We use a range of firm performance measures such as $R O A$, Tobin's Q (approximated by $M T B V$ ), and Earnings per share $(E P S)$. The results are presented in Table 8.

[Table 8 around here]

Columns (1), (2) and (3) of Table 8 give the results for the full sample withthe three measures of firm performance, $R O A, M T B V$ and $E P S$, respectively, and the indicator for business group affiliates as our main regressor 16 If the performance of business group firms differs from that of firms with dispersed holding structure, we would expect a statistically significant coefficient on the indicator for business group. However, this indicator is not statistically significant at conventional levels in any of the columns. Also, no difference in performance exists between business group affiliates with family CEOs, and those with outside CEOs. These results suggest no significant difference in performance for business group affiliates with concentrated shareholding and widely held standalones. This is consistent with Demsetz and Lehn's (1985) argument that the ownership structure of firms evolves in ways that are consistent with the proposition of value maximization.

\subsection{Robustness}

To test for the robustness of our baseline results we use a series of sample selection techniques and tests. Variable pay constitutes about one-third of Indian CEO pay contracts, which are largely in the form of a performance-based bonus. So, to test the robustness of our baseline estimates on pay-performance sensitivity we use the fraction of variable pay/total pay as the

\footnotetext{
${ }^{16}$ We test for the robustness of our results by using raw and industry-adjusted returns on the firms' stocks over one-year and three-year periods. The results are qualitatively similar and are in the online appendix.
} 
dependent variable. Family CEOs in group affiliates have a higher percentage of variable pay and higher performance sensitivity of variable pay than outside CEOs in group affiliates, and CEOs of stand-alone firms. The results are in panel A of Table 9.17

Next, we increase the sample of CEO turnovers by including all resignation events in our classification. This yields a sample of 493 events. Using this sample, we find that the sensitivity of CEO turnover to performance is comparable to our baseline estimates: CEO turnover in group affiliates with a family CEO is not sensitive to firm performance, but performance sensitivity of CEO turnover is comparable in group affiliates with outside CEOs and stand-alone firms. The results are in panel $\mathrm{B}$ of Table 9.

[Table 9 around here]

Note that one concern could be that business group affiliates are on average larger than unaffiliated firms. Thus the reported pay-performance sensitivity could reflect non-linear size effects. In our baseline specifications, we use the natural log of sales as a measure of firm size, which allows us to correct for any non-linearity induced by extreme values. In a different specification, reported in the online appendix, we use sales and sales-squared as measures of firm size. The coefficient on sales is positive and statistically significant but the coefficient on sales-squared is negative and not significant at conventional levels.

We also test for non-linearities in the performance sensitivity of CEO pay and CEO turnover by using different quartiles of firm performance. The results are similar to our baseline estimates. CEO turnover is more likely for stand-alone firms in the upper quartile of performance. This is consistent with the results of Gregory-Smith et al. (2009) and Homroy (2014), who attribute it to the higher likelihood of CEOs voluntarily resigning for better opportunities. In comparison, CEOs of business group affiliates are less likely to be motivated by the threat of dismissal or by the prospect of better opportunities.

Next, we use industry-adjusted firm performance to control for industry-specific heterogeneity at both two-digit and finer-grain three-digit standard industrial classification code levels. Firm $R O A$ is benchmarked with the median $R O A$ of the same two-digit industry group for that

\footnotetext{
${ }^{17}$ In unreported results we use the natural log of variable pay as the measure of CEO pay. The coefficient estimate of ROA is qualitatively similar to our baseline estimates.
} 
year. We estimate the specifications in Tables 3 and 4 using industry-adjusted ROA. Industry adjusted $R O A$ is more strongly associated with $\mathrm{CEO}$ turnover than industry-adjusted $M T B V$. This is not surprising given that stock market performance in emerging economies is a noisier signal of performance than in the developed economies (Demigüç-Kunt and Levine, 1995). The results are qualitatively similar and can be found in the online appendix.

We also investigate whether controlling shareholders extract their returns through sale of shares or receipt of dividends. In either case, their incentives will be closely aligned with that of minority shareholders, and will make them less prone to tunnel resources. To that end, we examine the time series variations in the shareholding of promoters, and the dividends paid. The proportion of shares held by promoters tends to be stable over time, and we find that promoters do not divest their stake significantly over time. We examine cases where the percentage of promoters' shareholdings has decreased over the sample period. In all cases (about 7\% of the business group affiliates), a decrease is associated with the issuance of new equity. Therefore these reductions appear to be financing decisions rather than control decisions. We discuss this in details in the online appendix. Similarly, we find no statistically significant difference in the dividends paid by group affiliates or stand-alone firms.

In unreported tests, we conduct a further set of robustness checks. First, we use firm fixed effects regressions with robust standard errors clustered at the firm level to check the validity of our baseline results. In order to do this, we exclude all time invariant firm level dummies from our models.Business Group Affiliates and Family CEO indicators) are not required in these specification but we keep the relevant interaction terms . We find that key associations persist: Carrot- type incentives dominate in business group affiliates with family CEOs and it have more weight in firms with higher \%Shareholding-Promoters, and stick type incentives dominates in other group. Moreover, business group affiliates and higher shareholding concentration is associated with higher long-term investments, but their association with firm performance measures are not statistically significant. Most of the firms in the banking and financial services industry are in the public sector and have been excluded in the initial sampling. We further exclude any remaining firms with significant interests in the financial services industry. The results with the reduced sample are qualitatively similar but less precise than our baseline estimates. 
Second, we use a matched sample of business group affiliates and unaffiliated firms with dispersed shareholding to test our baseline results 18 We match firms on the following observables: sales, board characteristics, institutional holdings, and HHI. Our results are qualitatively similar to the baseline estimates of incentive alignment, strategic objectives, and firm performance.

Third, we test the robustness of our tests for the performance of firms with different ownership structures using industry-adjusted-ROA. We find no significant differences in returns for business group affiliates and unaffiliated firms. Finally, we conduct robustness tests after winsorizing the full sample at $1 \%$, and $5 \%$ levels. The results with the $5 \%$ levels are less precise due to smaller sample-size, but are qualitatively similar to our baseline estimates.

\section{Conclusion}

Conventional wisdom in corporate finance states that business groups tend to be poorly governed, act as expropriation devices for controlling stakeholders, and are subpar performers compared to widely held firms. However, these views do not take into account the differing strategic objectives of firms with different ownership structures. We find that managerial incentive alignment mechanisms differ systematically across business group affiliates and in stand-alone firms. Business group affiliates with family CEOs have stronger pay-performance sensitivity (carrot-type incentive) but CEO turnover-firm performance sensitivity (stick-type incentive) dominates in stand-alone firms. Furthermore, in business group affiliates with outside CEOs, stick-type incentives dominate. Firms with different ownership structures face different agency and transaction costs, so the incentive alignment mechanisms are likely to differ as well. Our results are not consistent with the notion of weak governance in business group affiliates.

The differences in managerial incentive structure are reflected in firms' strategic choices. Faced with a stick-type incentive, CEOs of stand-alone firms choose shorter-term strategic objectives, while CEOs of business group affiliates with intergenerational stakeholding in the firm tend to invest in longer-term projects. Notwithstanding the differences in managerial incentive alignment and strategic objectives, we find no significant difference in firm performance between the two types of firms.

\footnotetext{
${ }^{18}$ We use a $\mathrm{k}: 1$ radius matching with radius $=0.2$, and check the sensitivity of our results to radius $=0.1$ and 0.3 .
} 
It is important to note that our results shed no light on the welfare implications of business group affiliation compared to widely held firms. They simply show that different firm ownership structures impose different constraints on the firm and,consequently, firms tend to use different resource allocation strategies. The welfare implications of business group affiliates depend on a range of factors such as their ability to use political connections, the role of other outside shareholders including institutional holding, and their towards social and environmental strategies. It is entirely plausible that controlling shareholders expropriate at the expense of minority shareholders in Indian business groups. Our results show that, even in that scenario, group affiliates are not generally less profitable than widely held firms. 


\section{References}

[1] Anderson, R., Reeb, D., 2003. Founding family ownership and firm performance: Evidence from the S\&P 500. J. Financ. 58, 1301- 1328.

[2] Armstrong, C.S., Vasistha, R., 2012. Executive stock options, differential risk-taking incentives, and firm value. J.Financ.Econ. 104(1), 70-88.

[3] Bertrand, M., Mehta, P., Mullainathan, S., 2002. Ferreting out tunneling: An application to Indian business groups. Q. J. Econ. 117 (1), 121-147.

[4] Berglof, E., Perotti, E., 1994. The governance structure of the Japanese financial keiretsu. J. Financ. Econ. 36, 259-284.

[5] Bertrand, M., Mullainathan, S., 2001. Are CEOs paid for luck? The ones without principles are. Q. J. Econ. 116 (3), 901-952.

[6] Black, B. S., Jang, H., Kim, W., 2006. Predicting firms' corporate governance choices: Evidence from Korea. J. Corp. Financ. 12, 660-691.

[7] Bryson, A., Forth, J., Zhou, M., 2014. Same or different? The CEO labour market in China's publicly listed companies. Econ. J. 124 (574), 90-108.

[8] Buis, M.L., 2010. Interpretations of interactions in nonlinear models, Stata Journal. 10, 305-308.

[9] Chakrabarti, R., Yadav, P.K., Megginson, W.L., 2007. Corporate governance in India. J. Appl. Corp. Financ. 20, 59-72.

[10] Claessens, S., Djankov, S., Fan, J. P. H., Lang, L. H. P., 2002. Disentangling the incentive and entrenchment effects of large shareholding. J. Financ. 57, 2741-2771.

[11] Conyon, M.J., Core, J., Guay, W.R., 2011. Are US CEOs Paid More Than UK CEOs? Inferences From Risk-Adjusted Pay. Rev. Financ. Stud. vol. 24 (2), 402-408.

[12] Conyon, M.J., He, L., 2011. Executive Compensation and Corporate Governance in China, J. Corp. Financ. 17, 1158-75. 
[13] Croci, E., Gonenc, H., Ozkan, N., 2012. CEO compensation, family control, and institutional investors in Continental Europe. J. Banking and Financ. 36(12), 3318-3335.

[14] Croci, E., and Petmezas, D., 2015. Do risk-taking incentives induce CEOs to invest? New evidence from acquisitions. J. Corp. Financ. 32, 1-23.

[15] Cronqvist, H., Nilsson, M., 2003. Agency costs and controlling minority shareholders. J. Financ. and Quant. Anal. 38, 695-719.

[16] Demigüç-Kunt, A., Levine, R., 1995. Stock market development and financial intermediaries: Stylized facts. World Bank Econ. Rev. 10, 291-321.

[17] Demsetz, H., Lehn, K., 1985. The structure of corporate ownership: Causes and consequences. J. Polit. Econ. 93 (6), 1155-1177.

[18] Dittman, I., Maug, E., Spalt, O., 2010. Sticks or Carrots? Optimal CEO Compensation when Managers are Loss Averse, J. Financ. 65(6), 2015-2050.

[19] Ederer, F., Manso, G., 2016. Is pay for performance detrimental to innovation? Man Sci. 59(7), 1496-1513.

[20] Gabaix, X., Landier, A., 2008. Why has CEO pay increased so much? Q. J. Econ. 121 (1), $49-100$.

[21] Gibson, M. S., 2003. Is corporate governance ineffective in emerging markets? J. Financ. and Quant. Anal. 38 (1), 231-250.

[22] Gopalan, R., Nanda, V., Seru, A., 2007. Affiliated firms and financial support: Evidence from Indian business groups. J. Financ. Econ. 86, 759-795.

[23] Gregory-Smith, I., Thompson, S., Wright, P.W., 2009. Fired or retired? A competing risks analysis of chief executive turnover. Econ. J. 119, 463-481.

[24] Holderness, C.G., 2009. The myth of diffuse ownership in the United States, Rev. Financ. Stud. 22, 1377-1408. 
[25] Holderness, C. G., Sheehan, D.P., 1988. The role of majority shareholders in publicly held corporations. J. Financ. Econ. 20, 317-346.

[26] Homroy, S., 2014. Was Adam Smith Right? Evidence of Compensating Differential in CEO Pay, Man Sch. 84(1), 1-24.

[27] Jameson, M., Prevost, A., Puthenpurackal, J., 2014. Controlling shareholders, board structure, and firm performance: evidence from India. J. Corp. Financ. 27, 1-20.

[28] Johnson, S., Boone, P., Breach, P., Friedman, E., 2000. Corporate governance in the Asian financial crisis. J. Financ. Econ., 58, 141-186.

[29] Kang, J. K., Shivdasani, A., 1995. Firm performance, corporate governance, and top executive turnover in Japan. J. Financ. Econ., 38, 29-58.

[30] Kaplan, S. N., 1994. Top executive rewards and firm performance: A comparison of Japan and the United States. J. Polit. Econ. 102, 510-546.

[31] Kaplan, S. N., 1997. Corporate governance and corporate performance: A comparison of Germany, Japan, and the US, in: D. H. Chew (Ed.), Studies in International Corporate Finance and Governance Systems, Oxford University Press, New York.

[32] Kaplan, S. N., Minton, B.A., 2012. How has CEO turnover changed? Int. Rev. Financ. 12 (1), 57-87.

[33] Khanna, T., Palepu, K., 2000. Is group affiliation profitable in emerging markets? An analysis of diversified Indian business groups. J. Financ. 55 (2), 867-891.

[34] Khanna, T., Yafeh, Y., 2007. Business groups in emerging markets: Paragons or parasites? J. Econ. Lit. 45 (2), 331-372.

[35] La Porta, R., Lopez-de-Silanes, F., Shleifer, A., 1999. Corporate ownership around the world. J. Financ. 54, 471-517.

[36] La Porta, R., Lopez-de-Silanes, F., Shleifer, A., Vishny, R.W., 1997. Law and finance. J. Polit. Econ. 106, 1113-1155. 
[37] Low, A., 2009. Managerial risk-taking behavior and equity-based compensation. J. Financ. Econ. 92, 470-490.

[38] Manso, G., 2011. Motivating Innovation. J. Financ. 66, 1823-1869.

[39] Masulis, R.W., Pham, P.K., Zein, J., 2011. Family business groups around the world: Financing advantages, control motivations, and organization choices. Rev. Financ. Stud. $24,3556-3600$.

[40] Masulis, R.W., Wang, C., Xie, F., 2009. Agency problems at dual-class companies. J. Financ. 64, 1697-1727.

[41] Maury, B., 2006. Family ownership and firm performance: Evidence from Western European corporations. J. Corp. Financ. 12, 321-341.

[42] Parrino, R., 1997. CEO turnover and outside succession: A cross-sectional analysis. J. Financ. Econ. 46, 165-197.

[43] Patibandla, M., 2006. Equity pattern, corporate governance, and performance: A study of India's corporate sector. J. Econ. Behav. and Organ. 59, 29-44

[44] Peters, F.S., Wagner,.A.F., 2014. The executive turnover risk premium. J. Financ., 69(4), $1529-1563$.

[45] Powers, E., 2005. Interpreting logit regressions with interaction terms: An application to the management turnover literature, J. Corp. Financ. 11, 504-522.

[46] Shleifer, A., Vishny, R. W., 1997. A survey of corporate governance. J. Financ. 52, 461-492.

[47] Siegel, J., Choudhury, P., 2012. A reexamination of tunneling and business groups: New data and new methods. Rev. Financ. Stud., 25, 1763-1798.

[48] Williams, R., 2012. Using the margins command to estimate and interpret adjusted predictions and marginal effects, Stata Journal 12, 308-331.

[49] Williamson, O. E., 1988. Corporate finance and corporate governance. J. Financ. 43, 567591. 


\section{Table 1}

Summary statistics. This table provides summary statistics for all the variables in our full sample. The sample is based on 4,143 observations of Indian firms for which financial and board data are available. Variables as described in appendix A.

\begin{tabular}{|c|c|c|c|c|c|c|}
\hline & $\mathrm{N}$ & Mean & Median & Std. Dev. & 10pct & 90 pct \\
\hline \multicolumn{7}{|c|}{ Panel A: Equity ownership variables } \\
\hline \%Shareholding-Promoters & 4,143 & 41.577 & 30.231 & 20.847 & 0.000 & 88.910 \\
\hline \%Shareholding-Institutions & 4,143 & 17.806 & 17.502 & 14.496 & 0.000 & 88.191 \\
\hline Family CEO & 4,143 & 0.374 & 0.288 & 0.484 & 0.000 & 1.000 \\
\hline \multicolumn{7}{|c|}{ Panel B: Managerial incentives and strategic choices variables } \\
\hline CEO Pay $(/ 1,000,000)$ & 4,143 & 4.635 & 3.145 & 8.988 & 0.272 & 17.000 \\
\hline Forced CEO Turnover & 4,143 & 0.145 & 0.154 & 0.352 & 0.000 & 1.000 \\
\hline Asset Turnover Ratio & 4,143 & 0.560 & 0.533 & 0.597 & 0.000 & 1.873 \\
\hline Current Ratio & 4,143 & 2.320 & 2.155 & 0.960 & 0.044 & 3.372 \\
\hline R\&D Expenditures & 2,625 & 0.047 & 0.000 & 0.081 & 0.000 & 0.608 \\
\hline Capital Expenditures & 2,337 & 0.069 & 0.001 & 0.077 & 0.000 & 0.636 \\
\hline \multicolumn{7}{|l|}{ Panel C: Board variables } \\
\hline Board Size & 4,143 & 9.948 & 7.449 & 3.327 & 4.000 & 33.000 \\
\hline \% Independent Directors & 4,143 & 51.797 & 50.003 & 16.181 & 48.331 & 93.500 \\
\hline$\%$ Technical Directors & 4,143 & 0.700 & 0.600 & 0.466 & 0.000 & 4.000 \\
\hline \multicolumn{7}{|c|}{ Panel D: Financial variables } \\
\hline Sales $(/ 1,000,000)$ & 4,143 & 522.592 & 438.430 & 2229.181 & 0.011 & 68215.141 \\
\hline Total Assets $(/ 1,000,000)$ & 4,143 & 77.120 & 89.122 & 264.820 & .210 & 6332.590 \\
\hline $\mathrm{ROA}$ & 4,143 & 0.083 & 0.064 & 0.111 & -0.847 & 1.826 \\
\hline MTBV & 4,143 & 1.419 & 0.988 & 2.917 & 0.187 & 13.521 \\
\hline EPS & 4,143 & 0.547 & 0.523 & 8.373 & -5.741 & 550.340 \\
\hline HHI & 4,143 & 0.690 & 0.671 & 0.102 & 0.025 & 0.768 \\
\hline Dividend Payout & 4,143 & 0.019 & 0.012 & 0.016 & 0.000 & 0.102 \\
\hline
\end{tabular}




\section{Table 2}

Industry distribution of different ownership structures.

This table illustrates the distribution of firms with different

ownership structures across the main industry classifications.

We find that both types of firms are present in all industry class

-ifications, but with varying proportions.

\begin{tabular}{lcc}
\hline \hline Industry & $\begin{array}{c}\text { Business Group } \\
\text { Affiliates }\end{array}$ & $\begin{array}{c}\text { Stand-Alone } \\
\text { Firms }\end{array}$ \\
\hline & & \\
Agricultural Products & 18 & 21 \\
Automobiles and Transport & 15 & 21 \\
Chemicals and Fertilizers & 18 & 15 \\
Food and Beverages & 14 & 31 \\
Industrials & 21 & 19 \\
Infrastructure & 12 & 24 \\
Jewellery, Gemstones and & 10 & 29 \\
Precious Metals & & \\
Leather and Footwear & 14 & 33 \\
Metals and Metallurgy & 23 & 13 \\
Minerals and Petroleum & 13 & 10 \\
Paper & 18 & 226 \\
Pharmaceuticals & 09 & 11 \\
Plastic Products & 11 & 12 \\
Services & 11 & 28 \\
Sustainable Energy & 08 & \\
Textiles and Garments & 11 \\
Total Number of Firms & & \\
\hline \hline
\end{tabular}




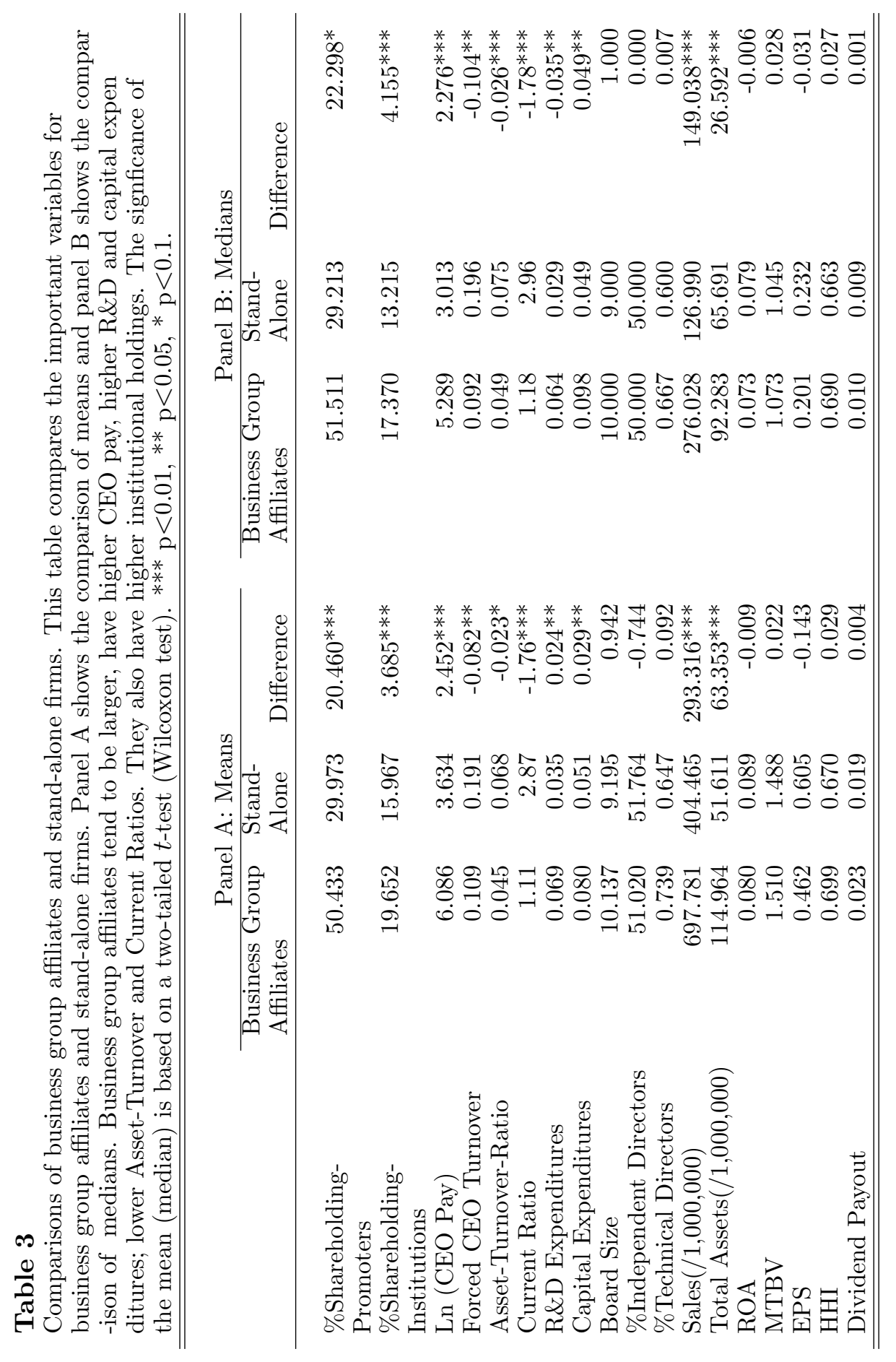




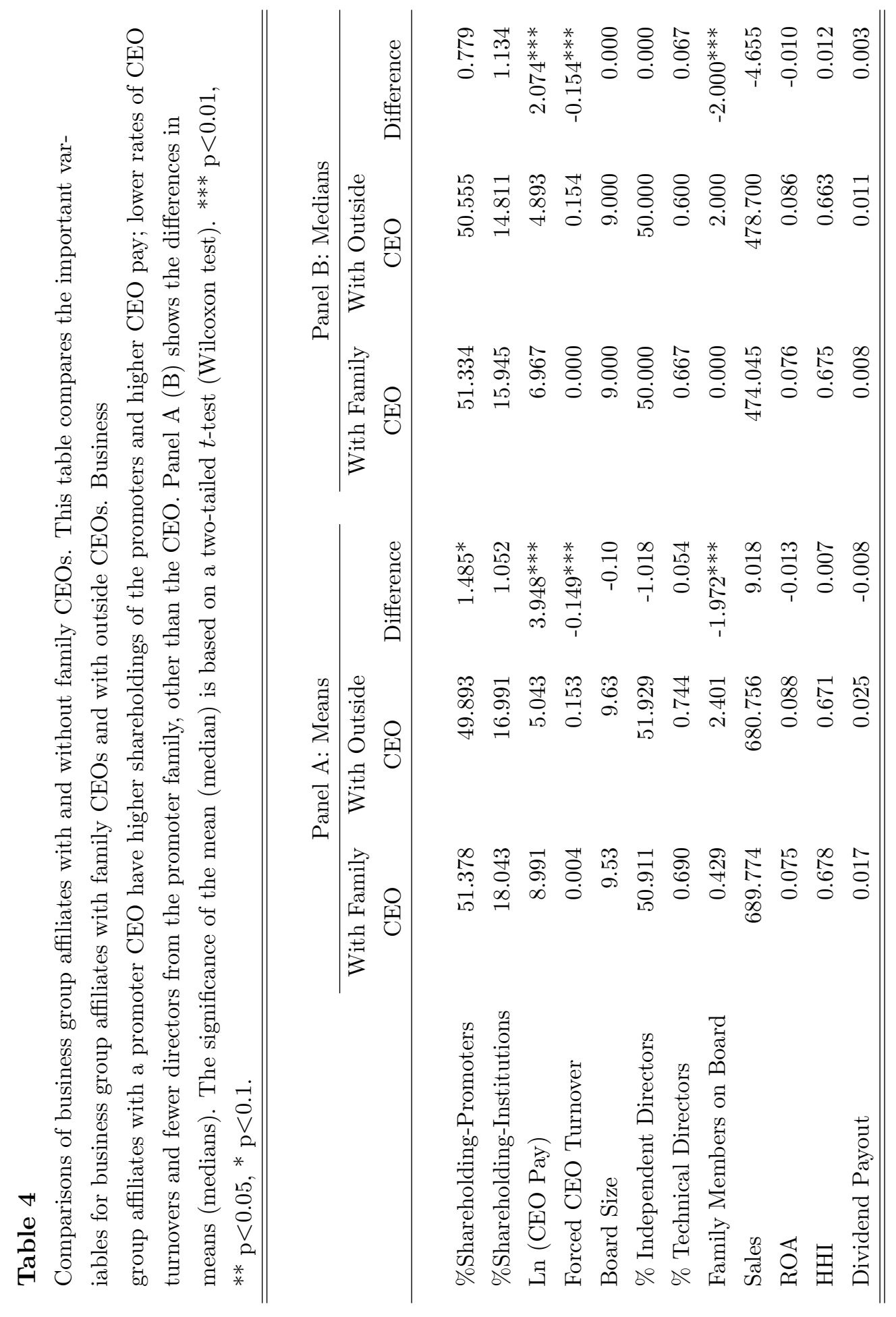




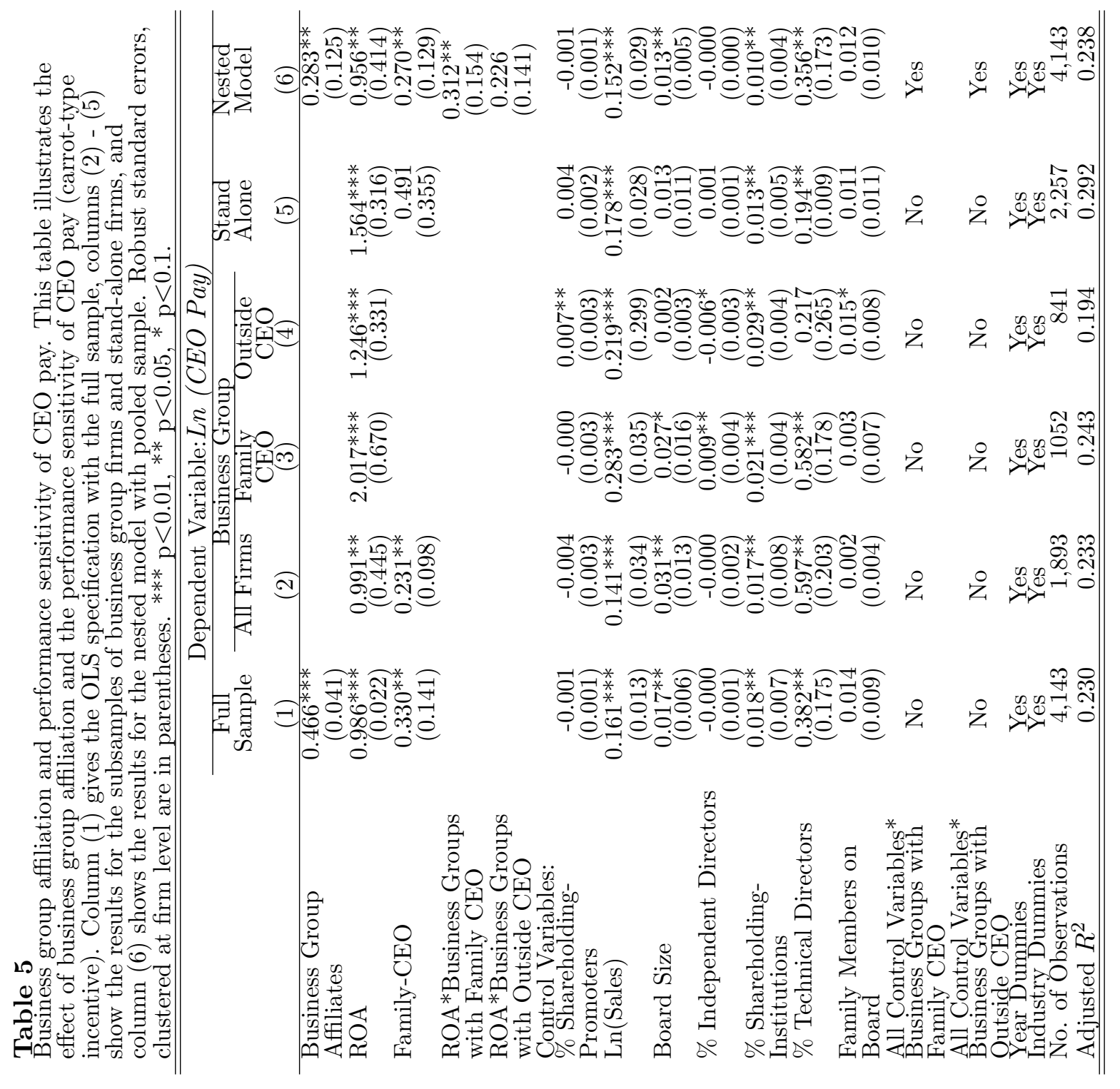




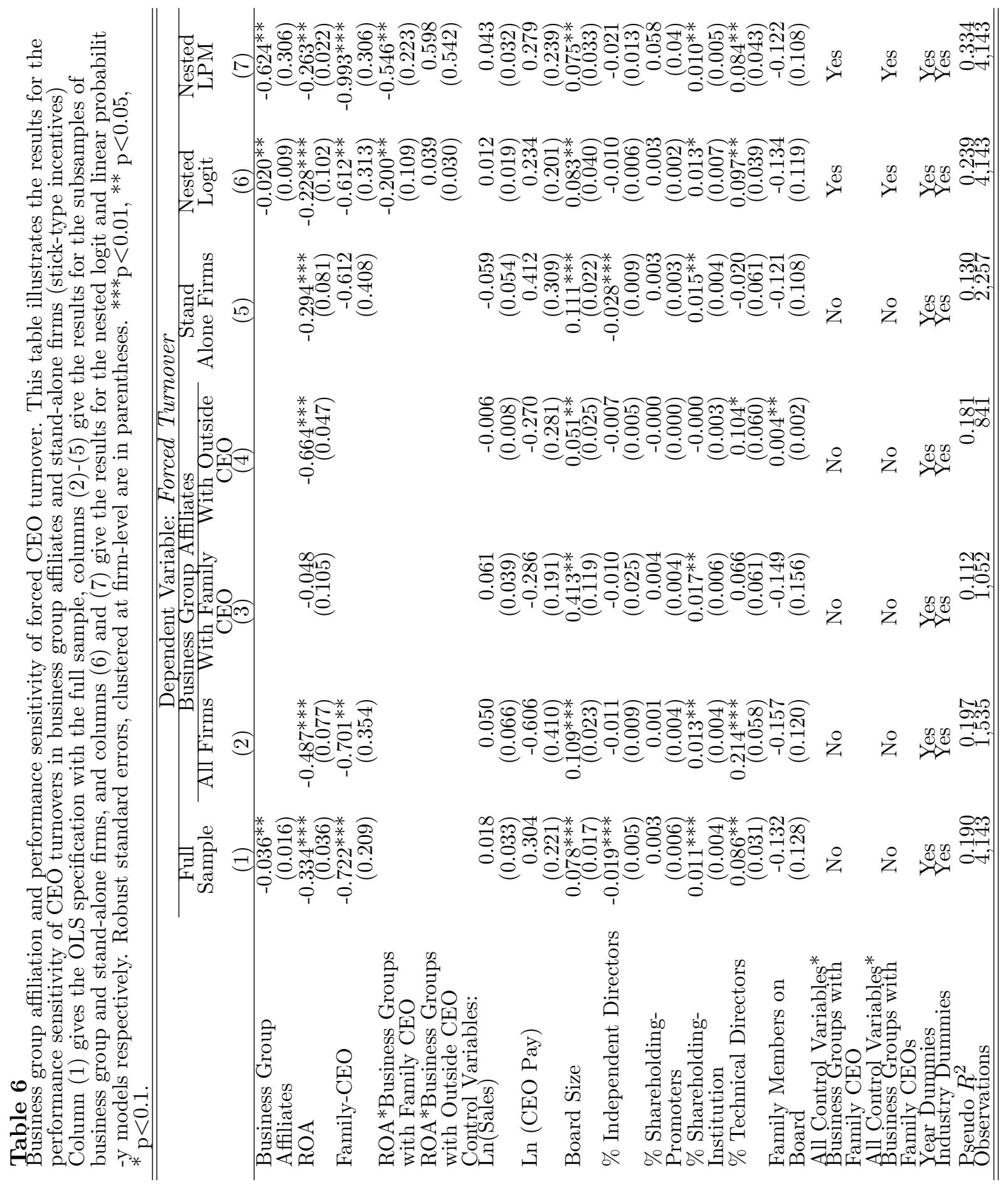




\section{Table 7}

Business group affiliation and firm strategy. This table illustrates the strategic choices of business group affiliates and stand-alone firms. In columns (1) and (2), the dependent variables reflect shorter term measures, the dependent variables in columns (3) and (4) reflect longer term strategic choices. Robust standard errors, clustered at firm level are in parentheses. ${ }^{* * *} \mathrm{p}<0.01$, ${ }^{* *} \mathrm{p}<0.05,{ }^{*} \mathrm{p}<0.1$

Dependent Variable

\begin{tabular}{l}
\hline Short term strategic measures \\
\hline Asset Turnover Current Ratio \\
Ratio
\end{tabular}

(1)

$(2)$

\begin{tabular}{cc}
\multicolumn{2}{c}{ Long term strategic measures } \\
\hline $\mathrm{R} \& \mathrm{D}$ & Capital \\
Expenditures & Expenditures
\end{tabular}

\begin{tabular}{|c|c|c|c|c|}
\hline & $(1)$ & (2) & $(3)$ & $(4)$ \\
\hline \multirow[t]{2}{*}{ Business Group Affiliates } & $-0.134^{* * *}$ & $-0.151^{* *}$ & $0.213^{* * *}$ & $0.118^{* *}$ \\
\hline & $(0.017)$ & $(0.044)$ & $(0.081)$ & $(0.063)$ \\
\hline \multirow{2}{*}{$\mathrm{ROA}$} & $1.198^{* * *}$ & $0.906^{* * *}$ & $1.832^{* * *}$ & $0.939^{* *}$ \\
\hline & $(0.059)$ & $(0.063)$ & $(0.118)$ & $(0.137)$ \\
\hline \multirow[t]{2}{*}{$\operatorname{Ln}($ Sales $)$} & 0.257 & 0.141 & 0.427 & 0.202 \\
\hline & $(0.332)$ & $(0.144)$ & $(0.629)$ & $(0.181)$ \\
\hline \multirow[t]{2}{*}{ Family-CEO } & -0.012 & 0.005 & $0.014^{* *}$ & $0.027^{* *}$ \\
\hline & $(0.009)$ & $(0.003)$ & $(0.005)$ & $(0.013)$ \\
\hline Family CEO* & -0.018 & -0.006 & $0.005^{* *}$ & $0.009^{* *}$ \\
\hline BusinessGroup & $(0.011)$ & $(0.005)$ & $(0.002)$ & $(0.004)$ \\
\hline \% Shareholding- & -0.001 & 0.007 & 0.013 & 0.009 \\
\hline Promoters & $(0.001)$ & $(0.006)$ & $(0.011)$ & $(0.010)$ \\
\hline \% Shareholding- & $-0.063^{* *}$ & $-0.042^{* * *}$ & $0.069^{*}$ & $0.033^{*}$ \\
\hline Institutions & $(0.026)$ & $(0.015)$ & $(0.041)$ & $(0.017)$ \\
\hline \multirow[t]{2}{*}{ Board Size } & $0.204^{*}$ & 0.089 & 0.294 & 0.211 \\
\hline & $(0.111)$ & $(0.056)$ & $(0.183)$ & $(0.169)$ \\
\hline \multirow[t]{2}{*}{ \% Independent Directors } & 0.020 & $0.026^{* * *}$ & 0.021 & 0.0135 \\
\hline & $(0.018)$ & $(0.010)$ & $(0.029)$ & $(0.009)$ \\
\hline \multirow[t]{2}{*}{ \% Technical Directors } & 0.037 & -0.018 & $0.726^{* * *}$ & 0.031 \\
\hline & $(0.046)$ & $(0.020)$ & $(0.145)$ & $(0.025)$ \\
\hline \multirow[t]{2}{*}{ Export / Sales (\%) } & $-0.001^{*}$ & 0.000 & $-0.001^{*}$ & 0.000 \\
\hline & $(0.000)$ & $(0.000)$ & $(0.000)$ & $(0.000)$ \\
\hline Year Dummies & Yes & Yes & Yes & Yes \\
\hline Industry Dummies & Yes & Yes & Yes & Yes \\
\hline No. of Observations & 4,143 & 4,143 & 2,625 & 2,337 \\
\hline Adjusted $\mathrm{R}^{2}$ & 0.109 & 0.128 & 0.077 & 0.093 \\
\hline
\end{tabular}




\section{Table 8}

Business group affiliation and firm performance. This table illustrates the performance effects of business group affiliation. The dependent variables in columns 1, 2, and 3 are $R O A, M T B V$, and $E P S$, respectively. Robust standard errors, clustered at the firm level are in the parentheses. ${ }^{* * *} \mathrm{p}<0.01,{ }^{* *} \mathrm{p}<0.05,{ }^{*} \mathrm{p}<0.1$

\begin{tabular}{|c|c|c|c|}
\hline & \multicolumn{3}{|c|}{ Dependent Variable } \\
\hline & $R O A$ & $M T B V$ & $E P S$ \\
\hline & (1) & $(2)$ & $(3)$ \\
\hline Business Group & -0.005 & 12.85 & -0.201 \\
\hline Affiliates & $(0.004)$ & $(9.40)$ & $(0.233)$ \\
\hline \multirow[t]{2}{*}{$\operatorname{Ln}($ Sales $)$} & $0.008^{* * *}$ & $-9.580^{* * *}$ & $0.118^{* *}$ \\
\hline & $(0.001)$ & $(2.956)$ & $(0.038)$ \\
\hline \multirow[t]{2}{*}{ Family-CEO } & $-0.018^{* * *}$ & $-20.051^{* *}$ & -0.267 \\
\hline & $(0.003)$ & $(9.062)$ & $(0.238)$ \\
\hline BusinessGroupAffiliates & 0.000 & 2.284 & -0.009 \\
\hline *Family CEO & $(0.000)$ & $(1.414)$ & $(0.009)$ \\
\hline \% Shareholding- & 0.000 & $1.695^{*}$ & 0.006 \\
\hline Institutions & $(0.000)$ & $(0.874)$ & $(0.004)$ \\
\hline \multirow[t]{2}{*}{ Board Size } & 0.000 & $-2.408^{*}$ & 0.036 \\
\hline & $(0.000)$ & $(1.455)$ & $(0.028)$ \\
\hline \multirow[t]{2}{*}{ \% Independent Directors } & 0.000 & 0.076 & 0.016 \\
\hline & $(0.000)$ & $(0.318)$ & $(0.009)$ \\
\hline \multirow[t]{2}{*}{$\%$ Technical Directors } & 0.013 & 0.004 & -0.028 \\
\hline & $(0.008)$ & $(0.011)$ & $(0.017)$ \\
\hline \multirow[t]{2}{*}{ Export / Sales (\%) } & 0.014 & 0.013 & 0.009 \\
\hline & $(0.010)$ & $(0.008)$ & $(0.006)$ \\
\hline Year Dummies & Yes & Yes & Yes \\
\hline Industry Dummies & Yes & Yes & Yes \\
\hline Observations & 4,143 & 4,143 & 4,143 \\
\hline Adjusted $R^{2}$ & 0.109 & 0.149 & 0.107 \\
\hline
\end{tabular}




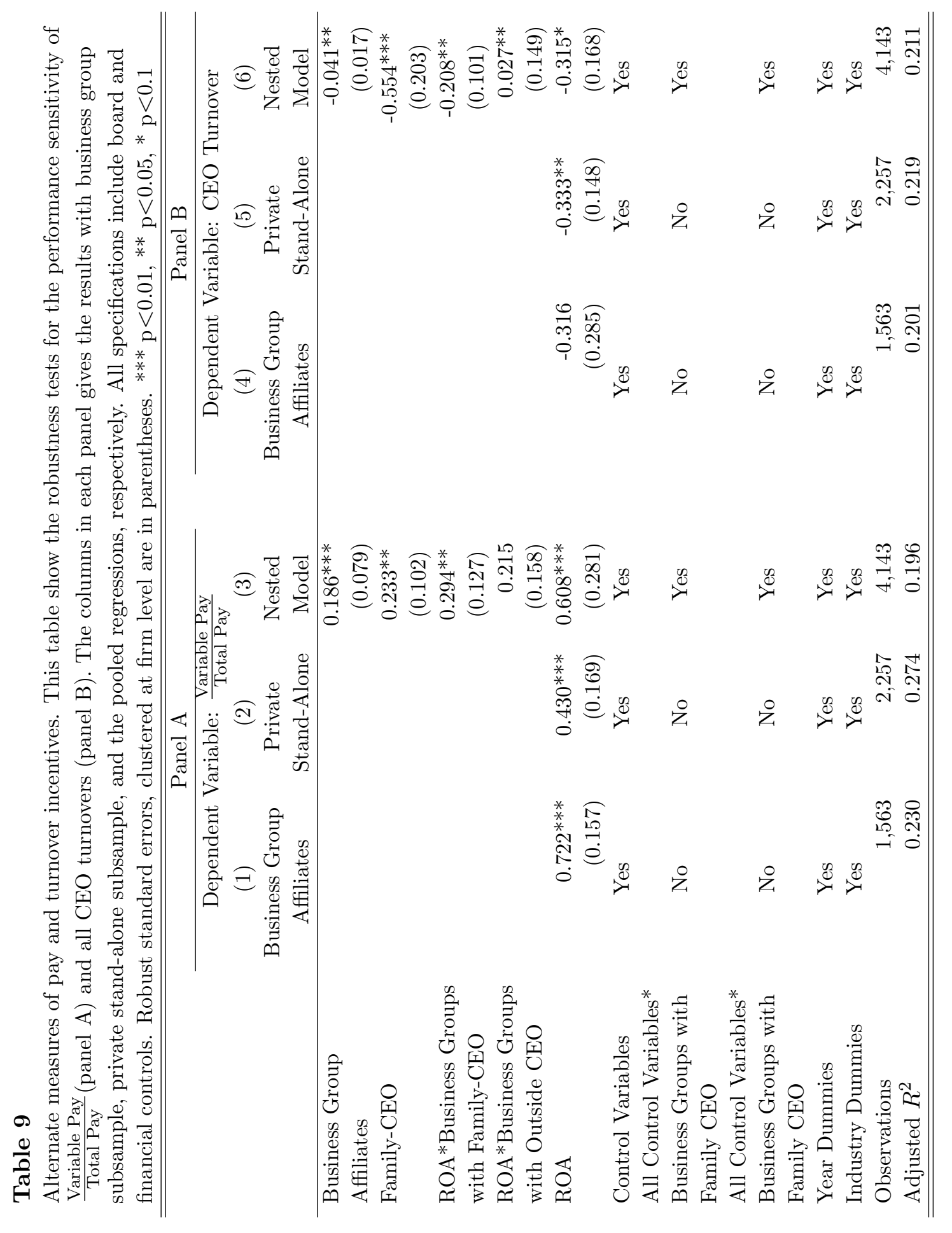




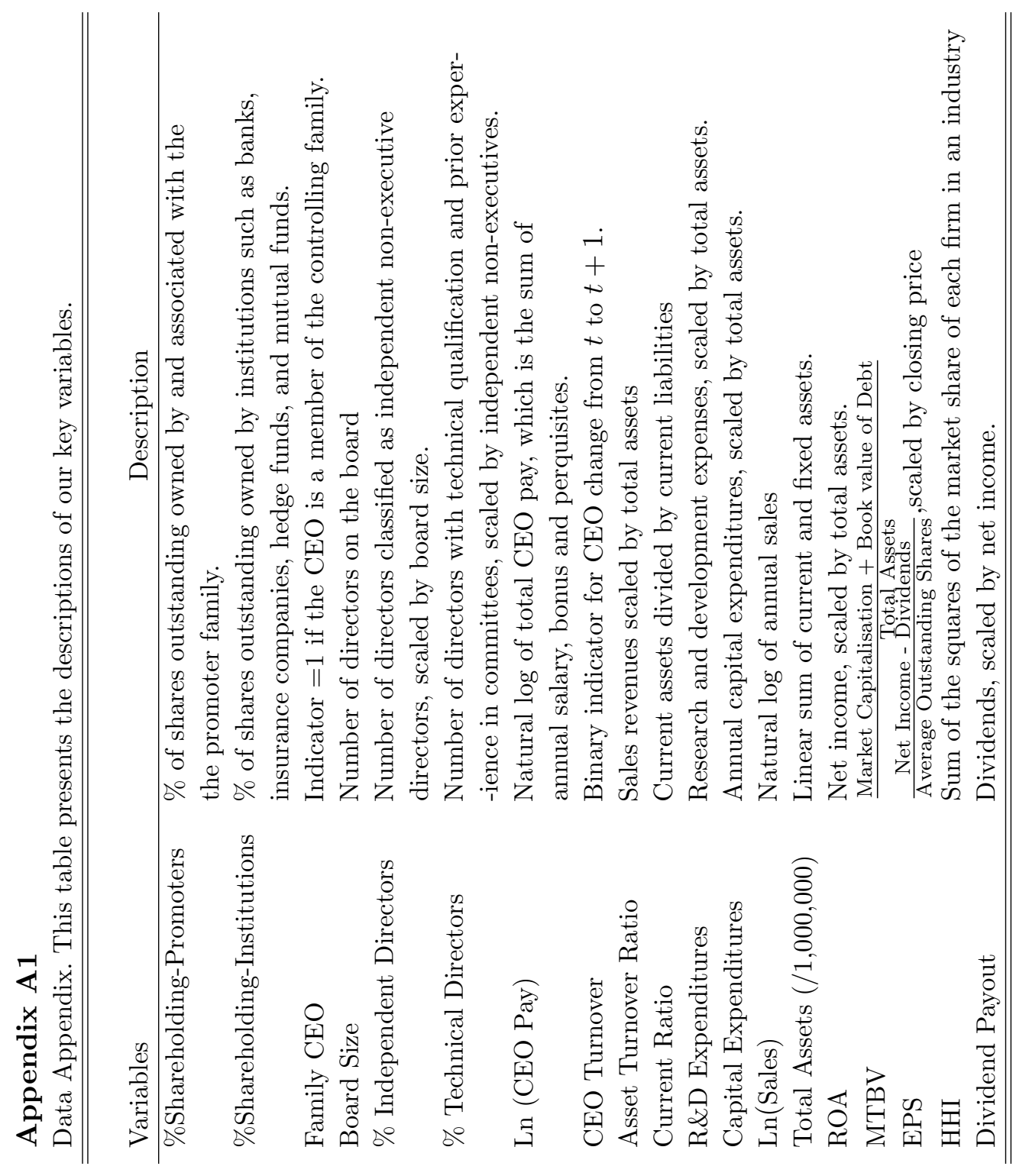

